\title{
Challenges Confronting the Administration of English Language Program: Secondary School Context in Nigeria
}

\author{
Ogunode Niyi Jacob \\ Federal University Wukari, Nigeria \\ ogunodejacob@gmail.com
}

\section{ARTICLE HISTORY}

Received : 2020-07-15

Revised : 2020-08-19

Accepted : 2020-08-19

\section{KEYWORDS}

Administration

Challenges

English language

Abaji Secondary School

Nigeria

\begin{abstract}
This objective of this study was to investigate the challenges facing the administration of English Language program in Senior Secondary schools in Abaji Area Council of Federal Capital Territory (FCT), Nigeria. The study used questionnaire as instrument for data collection. 80 respondents were selected from the entire population of English teachers and school administrators in Abaji. Purposive research techniques were employed to select the respondents. Research survey method was adopted for the study. To determine the reliability of the instrument, test and retest methods. The data collected were analysed using simple percentage, mean statistical and chi-square was employed to test the hypotheses. The result collected from the study led to the following conclusion that scant fund, shortage of professional English teacher, inadequate English language instructional materials, deficient English laboratory, poor capacity development of English language teachers and paltry motivation of English language teacher are the challenges affecting the effective administration of English language program in Abaji secondary Schools.
\end{abstract}

\section{Introduction}

By 2050, Nigeria is forecast to have 400 million people, meaning it will overtake the United States as the world's third-most-populous country. The starkness of this fact (its population is currently about 200 millions) illustrates the degree to which demography will shape Africa's future (www.economic.com). Nigeria has a federal system of government with 36 states and the Federal Capital Territory of Abuja. Within the states, there are 744 local governments in total. The country is multilingual, and home to more than 250 different ethnic groups.

The Nigerian educational system comprises of the basic education, the junior and secondary school education and the higher education. The secondary schools' education is the post-basic education. Secondary school education is also views as the education that prepares the students for career choice in the higher institutions.

The broad aim of secondary education within the overall national objectives is to prepare the students for higher education and for living a responsible life in society. Upon completion of nine years of basic education, most students proceed to the post-basic level, known as senior secondary education, for a period of three years. Nigeria has the largest secondary school education in Africa.
The Nigerian senior secondary schools have a diversified curriculum, with subjects program to wider the students' knowledge and outlook in real life. The official language for instruction in all the Nigerian senior secondary schools is English language except for special program like local language and international language program. The core subjects are English; mathematics; one major Nigerian language; one elective out of biology, chemistry, physics or integrated science; one elective out of English literature, history, geography or social studies; and agricultural science or a vocational subject. One of the three elective subjects may be dropped in the last year of the senior secondary course. The promotion of students from one class to another is determined by a combination of continuous assessment scores and end-of-term examinations. The Senior School Certificate examination is taken in the last year of senior secondary education and a certificate is awarded on successful completion and passing of a national examination, which is conducted by the West African Examinations Council or the National Examinations Council.

English language program in Nigeria is a program that is very important to the student academic progress. The students use English language for all their subjects except the local languages or international language. 
According to Oribabor (2009) the English language is regarded as the backbone of all other subjects taught in secondary schools. This is because it is the medium of instruction in most secondary and institutions of higher learning in Nigeria. In fact, the English language is one of the few core subjects recommended for secondary schools as stipulated in the National Policy of Education (2004). It is therefore, an essential pre-requisite for further education. At least a credit (C6) in English is a requirement even for science-based subjects. For effective communication one needs a high level of proficiency in the use of language. Our political and social circumstances make the use of English language imperative not only as a foreign language but as an official language. English language is probably the only tool that cuts across ethnic and cultural boundaries in Nigeria. For effective political participation and social interaction, one must have sufficient mastery of the English language (Oribabor, 2009).

Klein (1986) states that the fact that English language is essential for national understanding and cooperation. It is strategically important for educational advancement and for scientific and technological development. Juliana (2017) submits that the role English language plays in human development in Nigeria is the focal point of this paper. Basically, language is the most frequently used and the most highly developed form of human communication. Through language, people interact, share ideas and express their feelings. Without language, man would be incapable of a sustained and result oriented thinking. Education is unarguably an essential instrument for change and human development. At different levels of schooling in formal education, students are equipped with life-long knowledge and skills that would enable them realise their full potentials as human beings. However, all forms of education (formal, informal and non-formal) are realised through language; hence, language and education are inseparable.

In the Nigerian polity, English language plays the role of a second language, considering the multilingual nature of the country. English is also the language of instruction in the Nigeria education system. Not only is it the language of instruction, it is also a compulsory subject and a yardstick for evaluating a learner's school performance. The normal teaching learning process thrives on effective communication between the teacher and the learner. No matter how expertly, learning experiences are selected and organised, the ultimate objective of the teaching-learning exercise would not be achieved if the language of instruction is unfamiliar to the leaner.

This is where English language comes in. English language is indispensable to education in Nigeria, thus, it is a veritable tool for human development. English language program in Nigeria in recent time have drew the attention of many due to poor performance of students in both internal and external examinations. Banjo (2002) submits that observations and comments in Nigerian dailies and the chief examiners' reports show that the performance of secondary school students in English language is deteriorating.

Many factors have been identified as responsible for the poor performance of students in the secondary schools. Oribabor (2009) opines that several reasons have been advanced to explain this deterioration in the program of English language among the secondary school students. Among the reasons are lack of effective home stimulation which is related to the socio-economic status of the parents, and lack of relevant facilities -books, library facilities and language laboratory. The other reasons are acute shortage of competent and qualified teachers, defects of the examination system, non-challant attitude of competent and qualified teachers, over-crowded curriculum and the growing influence of youth subculture. In a nutshell, the reasons advanced are economic, cultural, social and curricula in nature (Tetteh \& Nuobeikaa, 2015). However, the teachers answered that the students participate in class. When teachers were asked whether there were problems in teaching English in the area, they all answered ,Yes ${ }^{\text {ee }}$ and outlined a numbers of problems. Prominent among the problems they outlined are: (a) Parents do not help their wards with school exercises at home, (b) Teachers are not given in-service training, (c) There aren't any teachers ${ }^{\text {ee }}$ Handbooks for English, (d) The teacher is not motivated at all, (e) There are no teaching and learning aid materials, (f) Most students cannot read English, (g) Most students cannot write simple sentences, (h) Most students cannot speak English well or at all in some cases.

Unoh (1986) also examined the situation of oral English in Nigerian secondary schools. He asserts that teaching of English pronunciation in Nigeria suffers from peculiar handicaps unknown to the teaching of English language or any other school subject (for that matter). For any subject to be effectively taught, there are at least two very important conditions that must be met: (i) a high degree of motivation on the part of both student and teacher; and (ii) the teachers' competence in the subject, and his or her mastery of the techniques of imparting knowledge in it.

Oluwayemisi (2015) submitted that In Nigeria, the teaching and learning of English is majorly done through the use of textbooks, dictionaries, chalkboards, workbooks and posters. Most schools lack modern technological devices like audio and video tapes, language laboratories, e textbooks, flash cards, internet facilities, newspapers etc. Thus as a 
nation, there is need to confront this issue so as to empower the teaching and learning of English.

The weaknesses of English language learners in higher education has been attributed to high school graduates' lack of knowledge on the what the university truly demands, poorly executed school and English language department curricula, inflexible teaching methodology, and sparse internal and external motivation to learn (Derin et al., 2020; Teevno, 2011). Aremu (2014) submitted that disunity and insecurity in Nigeria has led to the formation of different ethnic militants among which are; Maitatsine fundamentalists, the book haram and Zango-Kataf in northern Nigeria, Oodua progressive congress in Yoruba land, Egbesu in the defense of Biafra, Movement for the emancipation of Niger Delta (MEND) as well as other militants group in the country. These problems of disunity and insecurity play a significant role in dwindling the teaching and learning English language in Nigeria.

Akujobi \& Chukwu (2012) observed that, second language learners experience overwhelming challenges in learning the second language and these challenges are due to the differences between the forms and meaning of English and those of the native language. The weakness of English language learners in general has been attributed to various factors: lack of knowledge on the part of school graduates when they join the university, school and English language department curricula, teaching methodology, lack of the target language environment and the learners' motivation as well as others (Junaidi et al., 2020; Khan, 2011).

For effective administration of English language program in the Nigerian Senior secondary schools, there must be adequate professional teachers, adequate instructional materials, adequate infrastructural facilities like English laboratory and adequate funding of the program.

The poor performance of students in Abaji area council of Federal Capital Territory (FCT), Abuja, Nigeria in the recent external examination and the called by stakeholder in the educational sector in the local government area council motivated the reason for this research and secondly research gap that exist in this aspect of English language program in Nigeria and in Abaji area council in particular. Thus; this study is investigating the challenges facing the administration of English Language program in Senior Secondary schools in Abaji Area Council of FCT, Nigeria

There have been many researches in different aspects of English language in Nigeria. Augustine (2016) did a study that examined the challenges facing the teaching of English language in secondary schools and Joshua \& Lynda (2014) conducted a study that advocates for greater emphasis on the acquisition of oracy skills whereby this component of English. Usman (2015) research to investigate the English as a second language teachers' perception of a new Senior Secondary School English language curriculum objectives, content items, instructional materials/aids, modes of evaluation and the adequacy of the instructional personnel to successfully implement the curriculum in Nigeria State while Unoh (1986) also examined the situation of oral English in Nigerian secondary schools. Oluwayemisi (2015) observed that English Language teaching and learning is faced with myriads of challenges ranging from overpopulation to inadequate human power, government inconsistent policies, lacks of essential teaching facilities, students' laissez-faire attitude; mother tongue interference and many others.

The highlighted problems are not only common scenarios of the government owned schools but also exist in private institutions although with little variance. Lack of adequate language specialists as well as interlingua problem are some common features of schools in Nigeria and most parts of Africa. To solve these and many other problems, the paper opines that English learners must be extensive readers; teachers must reward efforts of learners so as to motivate their struggle to acquire the language skills; government as a matter of priority should make available necessary facilities that will empower teaching and learning of English and also school management should arouse the interest of English learners by providing relevant equipment and facilities for effective English teaching and learning (Yuzar, 2020).

According to Kannan (2009), students learn basic grammar at school level for the purpose of passing only in the tests and in the examinations and not to face any real life situations. Application-oriented advanced grammar is not taught in schools. Furthermore, adequate practice is not given to students to learn a language. The writer fully aligns with Kannan's opinion. It is obvious that students only read to pass English language but are not totally committed to its mastery; probably because learners are only taught and expect to regurgitate the experience rather than allowing them to self-discover the intricacies involved in immersing in a foreign language (Nursafira, 2020).

Oribabor (2009) did a paper that evaluated the appropriateness of teaching English language in some selected secondary schools etc. There is a research gap on the administration of English language program in the Nigeria secondary schools. Since the achievement of the objectives of English language program at the secondary schools depends on the effectiveness of the administration of the various secondary schools in the country. It is therefore 
important to carry out a research to investigate into the challenges facing the administration of English language program in secondary schools Abaji, Abuja, Nigeria.

The objective of this study is to investigate the challenges facing the administration of English Language program in Senior Secondary Schools in Abaji Area Council of FCT, Nigeria. This present study intended to focuses on inadequate fund, shortage of professional English teacher, inadequate English language instructional materials, inadequate English laboratory, poor capacity development of English language teachers and poor motivation of English language teacher are the challenges affecting the effective administration of English language program in Abaji secondary Schools.

\section{Literature Review}

Educational administration is the application of educational resources to achieve educational goals. Educational administration is the act and process of using resources in an effective and efficiency ways to attain the various objectives of educational institutions. Educational administration deals with the planning and organizing human and materials resources to realise the goals of educational institutions. Educational administration is the systematic arrangement of educational input in an operational means to achieve the set goals of educational institution. Nwiyi (2018) views Educational Administration as concerned with integrating the appropriate human and material resources that are made available and made effective for achieving the purposes of a program of an educational institution while (Osai \& Kalagbor, 2017) defines it as the process of identifying, mobilizing and utilizing scarce human and material resources relevant in education for the purpose of achieving specific educational goals efficiently and effectively. This process involves a careful and systematic use of methods, principles, plans and procedures necessary to achieve the educational objectives (Okoroma, 2016).

The term Administration doesn't refer to any single process or act. Nwiyi (2018) viewed the term as a broad umbrella encompassing a number of processes such as: planning, coordinating, controlling and being involved in other management processes and contribute to formulation of policies. In order to achieve these goals, the head of the educational organisation plans carefully various programs and activities. The educational organisation may be a school, college or university. The head organises these programs and activities with co-operation from other teachers, parents and students, motivating them and co-ordinating the efforts of staff members as well as directing and exercising control over them. The head evaluates the performance and progress of staff in achieving the purpose of the educational program, provides feedback to them and brings modification in the plans and programs of the institution when required. The totality of these processes which are directed towards realizing or achieving the purposes of the school is called educational administration (Nwiyi, 2018).

The objectives of educational administration include the following:

a) To ensure effective and efficient utilisation of resources in the educational management

b) To ensure that educational wastages are eliminated from the management of education

c) To ensure the all the aims and objectives of educational institutions are achieved within a set time

d) To ensure that educational resources available are prudently applied for the production of educational services

e) To ensure that educational plans are executed as planned.

English language program in Nigeria is one of the major program offered from the early child education to the higher education. English language is an important course in the Nigerian educational system. The objectives of English language program in Nigeria includes:

a) Building up English language skills and acquisition of communicative competence in secondary schools;

b) Enriching ESL learners' performance through newspapers;

c) Turning the textbook into genuine curriculum materials and not as a sacrosanct text to be used for English language curriculum;

d) Creating an enabling environment within the school premises for the promotion of language learning: the provision of libraries and promotion of activities in and outside the school in order to reinforce the normal efforts of teachers;

e) Taking a more holistic view of a language as an audio-oral-syntactico-lexical complex and so paying greater attention to the teaching and examination of English language in use as opposed to the restricted code English language extracted from the larger corpus for examination purposes only (Obanya, 2002).

It is a compulsory program from the basic education to the higher education. Students must meet the program in every phase of the educational system. Juliana (2017) opined that English is the language of education in Nigeria. It is the language of instruction from upper primary education, through secondary and tertiary education in Nigeria. The state of English as a Second Language in Nigeria coupled with its numerous roles compels every Nigerian citizen to 
learn and to speak it. This paper therefore submits that if English language is the medium through which the concepts in education are expressed and acquired, then, it is a primary instrument for human development in Nigeria. English language has not only engineered human development through education, it has also conferred on Nigerians other significant privileges both on the home front and the global scene.

The teaching and learning of English program in Nigeria have attracted many researchers to carry out studies in it. Augustine (2016) did a study that examines the challenges facing the teaching of English language in secondary schools in Aniocha South Local Government Area of Delta State Nigeria. The purpose of the research is to determine the basic factors that can be attributed to poor usage of the language by school leavers and graduates. The methodology of the study was the use of questionnaire to elicit response from English teachers. The questions contained in the questionnaire covered areas of perceived difficulties in the teaching and learning of English, the motivation of teachers, availability and use of teaching resources, training of teachers and exposure to modern teaching methods. Findings from the study show that the problem of poor usage of English is a combination of various factors which include problem of indiscipline among students, teachers' inadequacy to teach effectively, inadequate coverage of course contents, etc. Recommendations are made.

Joshua \& Lynda (2014) conducted a study that advocates for greater emphasis on the acquisition of oracy skills whereby this component of English is totally neglected in our higher schools. It identifies and examines some of the major challenges that the teaching of oral English could face; thereby proffering some possible solutions that could improve the teaching of oral English in our secondary schools. Questionnaires were used to seek teachers' and students' opinions concerning the problem. The research participants consisted of the teachers of English Language and students, particularly, Senior Secondary Schools Students (SSSI-SSS III) within four selected schools. The results have shown that interference of mother tongue, unqualified teachers and dearth of relevant teaching materials are the major challenges. The study suggested that (i) a high degree of motivation in both students and teachers, and (ii) the teachers' competence in the subject and their mastery of the techniques of imparting knowledge in it are the basic the solutions. Teachers and Language instructors should identify these problems, face the challenges through practical classes and improvisation and also insist on standards.

Usman (2015) conducted a research that investigated the English as a second language teachers' perception of a new Senior Secondary School English language curriculum objectives, content items, instructional materials/aids, modes of evaluation and the adequacy of the instructional personnel to successfully implement the curriculum in Niger State, Nigeria. The research sought answers to the five research questions to guide the study. A survey research method was used and a questionnaire designed patterned on Likert's five-point scale was used for data collection. The content validity of the questionnaire was established through critical examination by experienced teachers. The reliability of the questionnaire was established on the analyses of result of its administration using test-retest method on ten randomly selected experienced secondary school English language teachers. The reliability coefficient value of 0.843 was arrived at using the Pearson product moment correlation coefficient statistical technique. The $0.843 \mathrm{r}$ value is above the reliability coefficient acceptable level.

The population in this study was two hundred and fifty English Language teachers and sixty were selected for use through the simple balloting and stratified random sampling techniques. The sixty English teachers used as respondents were visited in their schools by the researcher and the respondents responded to the questionnaire there and then except for some few copies that had to be left with H.O.D., Language for administration and collected on second visit. The data was analysed using the frequency counts, simple percentile and mean statistical techniques to answer the research questions and the $\mathrm{t}$ test statistical technique was used in testing the paired null hypotheses.

The results revealed that the English teachers' perception of the curriculum objectives and content items was favourable except that they opined that the time allocated for the coverage of the content items was inadequate. Findings on other aspects of the curriculum were that the recommended instructional materials and teaching/learning aids were neither provided nor available for procurement; teachers may be bias in the use and conduct of continuous assessment and the recommended modes of evaluation could be expensive to produce. Other findings are that professional English teachers were inadequate in number and in preparation to implement the new curriculum and the available teachers should be encouraged to attend both inservice or on-the-job training on full-time or part-time basis and workshops to make them better qualified and prepared to teach the new English curriculum.

Unoh (1986) also examined the situation of oral English in Nigerian secondary schools. He asserts that teaching of English pronunciation in Nigeria suffers from peculiar handicaps unknown to the teaching of English language or any other school subject (for that 
matter). For any subject to be effectively taught, there are at least two very important conditions that must be met: (i) a high degree of motivation on the part of both student and teacher; and (ii) the teachers' competence in the subject, and his or her mastery of the techniques of imparting knowledge in it. While the aforementioned conditions are rarely achieved in the teaching of English Language, they are also hardly met in the case of the teaching and learning of English pronunciation.

Sujatha, Salaam \& Opoku (2017) carried out a study that to find out if the qualification of the English teachers has direct or indirect bearing on the performance of the students in English language. The topic was built on the assumption, apparently shared by most people especially our educational policy makers that any fluent speaker of English automatically becomes an effective English teacher. Two secondary schools in the tamale metropolis were selected for the study. Questionnaires were distributed to the students and teachers in the selected schools. The responses were analysed using descriptive survey. The study found out that teacher's qualification does affect student's performance. Recommendations were made on how to improve on the quality of teachers already in the classroom.

Oribabor (2009) did a paper that evaluated the appropriateness of teaching English language in some selected secondary schools in both Urban (Ile-Ife) and Rural (Ibodi) areas respectively of former Oranmiyan and Atakunmosa Local Government Areas of Osun state, Nigeria. 150 Senior Secondary School students whose ages ranged from seventeen years six months to eighteen years three months were used for the study. Also investigated were the attitudes of the teachers to the philosophy and implementation of the new English Language curriculum. The interest of the students in the new English language curriculum was also assessed. An attitude scale and a questionnaire were used to test the relationship among the variables identified for the study. Data collected in the study were analysed using percentages and t-test to test the hypotheses generated for the study.

Results showed that teachers in both urban and rural settings did not differ in their opinion that they were not involved in the planning of the new English language program. It was discovered by the paper that there is need to involve the teachers in both rural and urban schools settings in the identification and planning of program objectives. The non-availability of recommended instructional materials was equally discovered. The paper suggested the need for an urgent re-assessment of existing strategies for implementing the new English language program. As to whether or not teachers have been involved in the planning of the new English language program, teachers show that only four per cent, i.e., 1 of the teachers in urban area indicated that he has been involved. In contrast as shown, ninety-six percent i.e. 24 of the teachers indicated that they have not been involved. In the rural areas on the contrary thirty-six per cent, i.e., 9 of the teachers indicated that they have been involved in planning the English language program.

In summary, twenty per cent of all the teachers in both urban and rural settings indicated their involvement in planning the new English language program. Eighty percent of the teachers in both urban and rural settings have therefore not been involved in the planning of the English language program. It is clear, from the findings on this particular item, that most of the teachers have not been involved in the planning of the program. There is need to involve teachers because they are the people to implement the program. It must have been observed that a greater percentage or thirthy-six of the teachers in the rural area claimed that they have been involved in the planning of the program; while only four per cent of those in town claimed similar involvement. Further discussion with the teachers in an interview revealed, however, that the teachers in the rural setting did not understand what is meant by involvement in planning when they answered the question. This is because they later confessed that they have never been actually involved. In short it appears that none of the teachers interviewed had actually been involved in the planning in order to ensure successful implementation of the program. Findings of this study therefore indicated a major omission by not involving teachers at the planning stage (Oribabor, 2009).

Oribabor (2009) several reasons have been advanced to explain this deterioration in the program of English language among the secondary school students. Among the reasons are lack of effective home stimulation which is related to the socioeconomic status of the parents, and lack of relevant facilities-books, library facilities and language laboratory. The other reasons are acute shortage of competent and qualified teachers, defects of the examination system, nonchalant attitude of competent and qualified teachers, over-crowded curriculum and the growing influence of youth subculture. In a nutshell, the reasons advanced are economic, cultural, social and curricula in nature. Juliana (2017) submitted that most often, language teachers at all levels of education in Nigeria encounter many problems in their attempt at improving the teaching and learning of English language. Some of the problems include: lack of resources for language teaching, inadequate knowledge of current trends in the teaching and learning of a second language, inconsistencies in the language policy provision on education, attitude and psychological problems on the part of the learners and unprofessionalism in handling the subject. 
From the reviewed literatures, it is clear that that issue concerning challenges facing the administration of English language program in Nigeria and in Abaji area council of FCT, Abuja is silent. Based on this research gap, this study is aimed to find out the challenges facing the administration of English language program of Secondary Schools education in Abaji, FCT, Nigeria.

\section{Method}

The objective of this study was to investigate the challenges facing the administration of English Language program in Senior Secondary schools in Abaji Area Council of FCT, Nigeria. The study used questionnaire as instrument for data collection. Likeert's four-point scale. 80 respondents were selected from the entire population of English teachers and school administrators in Abaji. Purposive research techniques were employed to select the respondents. Research survey method was adopted for the study. To ensure of the validity of the questionnaire, sole lecturers of English language were given the questionnaire to crosscheck for corrections. To determine the reliability of the instrument, test and retest method was used for the study and copies of the questionnaire were administered to ten selected English language teachers in a nearby local government council two times after two weeks. Pearson product-moment correction co-efficient method was used. The result collected for $r$ was 0.78 . The questionnaire was administered to the respondents through the help of English language teachers who volunteer to visit all the selected sampled secondary schools in the areas. The data collected were analysed using simple percentage, mean statistical and chi-square was employed to test the hypotheses.

\section{Findings}

H0: Inadequate fund is not affecting the effective administration of English language program in Abaji secondary Schools.

H1 Inadequate fund is affecting the effective administration of English language program in Abaji secondary Schools.

Table 4.1 The r- calculated

\begin{tabular}{cccccc}
\hline Variables & $\mathrm{N}$ & Df & r-cal & $\begin{array}{c}\text { r- } \\
\text { table }\end{array}$ & Result \\
\hline $\mathrm{X}$ & 80 & 78 & 0.265 & 0.195 & Significant \\
$\mathrm{Y}$ & 80 & & & & \\
\hline
\end{tabular}

The table 4.1 showed that the $\mathrm{r}$ calculated is 0.265 which is greater than the $t$ calculated of value 0.195 . This means that inadequate fund is affecting the effective administration of English language program in Abaji secondary Schools.
H0: Shortage of professional English teacher is not affecting the effective administration of English language program in Abaji secondary Schools

$\mathrm{H} 2$ Shortage of professional English teacher is affecting the effective administration of English language program in Abaji secondary Schools.

Table 4.2 The r- calculated

\begin{tabular}{llllll}
\hline Variables & $\mathrm{N}$ & Df & r-cal & $\begin{array}{l}\text { r- } \\
\text { table }\end{array}$ & Result \\
\hline $\mathrm{X}$ & 80 & 78 & 0.271 & 0.195 & Significant \\
$\mathrm{Y}$ & 80 & & & & \\
\hline
\end{tabular}

The table 4.2 showed that the $\mathrm{r}$ calculated is 0.271 which is greater than the $t$ calculated of value 0.195 . This means that shortage of professional English teacher is affecting the effective administration of English language program in Abaji secondary Schools.

H0: Inadequate English language instructional materials is not affecting the effective administration of English language program in Abaji secondary Schools

H3 Inadequate English language instructional materials is affecting the effective administration of English language program in Abaji secondary Schools.

Table 4.3 The r- calculated

\begin{tabular}{llllll}
\hline Variables & $\mathrm{N}$ & Df & r-cal & $\begin{array}{l}\text { r- } \\
\text { table }\end{array}$ & Result \\
\hline $\mathrm{X}$ & 80 & 78 & 0.280 & 0.195 & Significant \\
$\mathrm{Y}$ & 80 & & & & \\
\hline
\end{tabular}

The table 4.3 disclosed that the $r$ calculated is 0.280 which is greater than the $t$ calculated of value 0.195 . This means that inadequate English language instructional material is affecting the effective administration of English language program in Abaji secondary Schools.

H0: Inadequate English laboratory is not affecting the effective administration of English language program in Abaji secondary Schools.

H4 Inadequate English laboratory is affecting the effective administration of English language program in Abaji secondary Schools.

Table 4.4 The r- calculated

\begin{tabular}{llllll}
\hline Variables & $\mathrm{N}$ & Df & r-cal & $\begin{array}{l}\text { r- } \\
\text { table }\end{array}$ & Result \\
\hline $\mathrm{X}$ & 80 & 78 & 0.267 & 0.195 & Significant \\
$\mathrm{Y}$ & 80 & & & & \\
\hline
\end{tabular}

The table revealed that the $r$ calculated is 0.267 which is greater than the $t$ calculated of value 0.195 . This means that inadequate English laboratory is affecting the effective administration of English language program in Abaji secondary Schools. 
H0: Poor capacity development of English language is not affecting the effective administration of English language program in Abaji secondary Schools .

H5 Poor capacity development of English language is affecting the effective administration of English language program in Abaji secondary Schools.

Table 4.5 The r- calculated

\begin{tabular}{llccll}
\hline Variables & $\mathrm{N}$ & Df & r-cal & $\begin{array}{l}\text { r- } \\
\text { table }\end{array}$ & Result \\
\hline $\mathrm{X}$ & 80 & 78 & 0.283 & 0.195 & Significant \\
$\mathrm{Y}$ & 80 & & & & \\
\hline
\end{tabular}

The table disclosed that the $\mathrm{r}$ calculated is 0.283 which is greater than the $t$ calculated of value 0.195 . This means that poor capacity development of English language is affecting the effective administration of English language program in Abaji secondary Schools.

H0: Poor motivation of English language teacher is not affecting the effective administration of English language program in Abaji secondary Schools.

H6 Poor motivation of English language teacher is affecting the effective administration of English language program in Abaji secondary Schools.Table 4.6 The r-calculated

\begin{tabular}{llllll}
\hline Variables & $\mathrm{N}$ & Df & r-cal & $\begin{array}{l}\text { r- } \\
\text { table }\end{array}$ & Result \\
\hline $\mathrm{X}$ & 80 & 78 & 0.290 & 0.195 & Significant \\
$\mathrm{Y}$ & 80 & & & & \\
\hline
\end{tabular}

The table revealed that the $\mathrm{r}$ calculated is 0.290 which is greater than the $t$ calculated of value 0.195 . This means that poor motivation of English language teacher is affecting the effective administration of English language program in Abaji secondary Schools.

\section{Discussion}

\subsection{Inadequate Fund}

Result collected showed that the $r$ calculated is 0.265 is more than the $t$ calculated of value 0.195 . This means that inadequate fund is affecting the effective administration of English language program in Abaji Secondary Schools. One of the major problem facing the implementation of English language program in the Nigerian secondary schools is the problem of inadequate funding. Generally, the annual budgetary allocation for the ministry of education is always below $15 \%$ and this is affecting the development of programs at the basic, secondary and higher education. According to Femi (2016), the most pressing problems for Nigeria's secondary school education remains the severe underfunding. The Federal government, which is responsible for sustaining public educational institutions, has over the past decade not significantly increased the share of the government budget dedicated to education, despite exploding student numbers. Between 2003 and 2013 education spending fluctuated from 8.21 per cent of the total budget in 2003 to 6.42 per cent in 2009 , and to 8.7 per centage in 2013. In 2014, the government significantly increased education spending to 10.7 per cent of the total budget. The poor allocation to the ministry of education is preventing the effective administration and management of the sector. This result confirms the findings of Oluwayemisi (2015) who observed that lack of basic facilities and equipment is a challenge that hinders effective teaching and learning of English Language. Most schools and colleges in Nigeria lack essential equipment which could have strengthen learners 'skills. Most schools do not have language laboratory and well equipped libraries.

\subsection{Shortage of Professional English Teacher}

The result collected showed that the $r$ calculated is 0.271 which is greater than the $t$ calculated of value 0.195 . This means that shortage of professional English teacher is affecting the effective administration of English language program in Abaji secondary Schools. One of the major problems facing the administration of English language program in the secondary schools is inadequate professional teachers. English language teachers are inadequate in majorities of the secondary schools in Nigeria and this is preventing the effective administration of the program.

This result is in agreement with Oluwayemisi (2015) who submits that English Language teaching and learning is faced with myriads of challenges ranging from overpopulation to inadequate human power, government inconsistent policies, and lack of essential teaching facilities, students' laissez -faire attitude; mother tongue interference and many others. The highlighted problems are not only common scenarios of the government owned schools but also exist in private institutions although with little variance. Lack of adequate language specialists as well as Interlingua problem are some common features of schools in Nigeria and most parts of Africa.

\subsection{Inadequate English Language Instructional Materials}

The table three results revealed that the $r$ calculated is 0.280 is more than the $t$ calculated of value 0.195 . This means that inadequate English language instructional materials is affecting the effective administration of English language program in Abaji secondary Schools. 


\subsection{Inadequate English Laboratory}

Result from table four above showed that the $r$ calculated is 0.267 is more than the $t$ calculated of value 0.195. This means that inadequate English laboratory is affecting the effective administration of English language program in Abaji Secondary Schools. English language laboratories are very important for the implementation of the English language program in the secondary schools. It is unfortunate that majorities of secondary school in Nigeria do not have English language labs. The inadequate of the resources is affecting the administration of English language program in the Nigerian Secondary schools. This result is in agreement with the discovered of Oluwayemisi (2015) who observed that lack of basic facilities and equipment is a challenge that hinders effective teaching and learning of English Language. Most schools and colleges in Nigeria lack essential equipment which could have strengthened learner' skills. Most schools do not have language laboratory and well equipped libraries.

\subsection{Poor Capacity Development of English Language Teachers}

The table five result showed that the $\mathrm{r}$ calculated is 0.283 which is greater than the $t$ calculated of value 0.195 . This implies that poor capacity development of English language is affecting the effective administration of English language program in Abaji secondary Schools. Many English language teachers teaching in the Nigerian secondary schools do not go for training and retraining program because the opportunities provided by the government are limited. Obanya (2004) observed that the era where all that was required of a teacher was subject matter knowledge is far gone. There is utmost need for improved teacher education which is more than a necessity in the 21 st century where technological development and advancement has become a main stay. The association for teacher education in Europe (2006) submits that teaching is 'a profession that requires continuing professional development, reflective thinking, responsibility, autonomy, creativity, and research and personal judgments. The result collaborates with the submission of Femi (2016) who submits that majorities of Nigerian teachers lack effective capacity development program to improve their skills and knowledge in the classroom.

\subsection{Poor Motivation of English Language Teacher}

From the results displayed in the six tables, the $r$ calculated is 0.290 is more than the $t$ calculated of value 0.195 . This means that poor motivation of English language teacher is affecting the effective administration of English language program in Abaji secondary Schools. Motivation is defined as a force that causes an individual to take some actions in order to achieve certain goals. Many professional teachers teaching in the Nigerian educational system are not happy. The state of motivation is poor and this is affecting their commitment to work. The implementation of English language program is facing program of implementation because many of the teachers teaching the program are not motivated to give their best. Adelabu (2005) discovered in Nigeria that teacher's motivation is very poor and teachers are also dissatisfied with their working environment and salary conditions. The reason behind the poor motivation of teachers is that they having low salaries as compared to other professionals, poor work environment, no decision making authority, and also not giving them opportunity of develop their career.

\section{Conclusion}

English language program is one of the major subject that every student must pass it at credit level before proceeding to the next class in the Nigeria senior secondary schools. It is crucial for the schools to the development of the Nigerian educational sector. It is unfortunate that English language program have not been given maximum attention needed in the Secondary schools education.

There are many challenges facing the administration of the program in the Nigerian secondary schools resulting to poor performance of students in both the internal and external exams. This study was designed to investigate the challenges facing the administration of English language program in Abaji area council Secondary Schools of FCT, Nigeria.

The result collected from the study led to the following conclusion that inadequate fund, shortage of professional English teacher, poor English language instructional materials, paltry English laboratory, deficient capacity development of English language teachers and meager motivation of English language teacher are the challenges affecting the effective administration of English language program in Abaji secondary Schools. Based on these findings, the researcher hereby recommends the following:

a) The government should increase the allocation for administration of English language program in the FCT especially in Abaji area council.

b) The government should employ more professional English teachers and deploy them to various secondary schools across the FCT and in Abaji area councils in particular

c) More instructional materials should be provided for all the secondary schools in FCT and in Abaji area council to aid English teachers to deliver quality instruction. 
d) Training and retraining program should be constantly organise for English language teachers in Abaji area council to help them update their teaching methods and classroom management. Inservice opportunities should be provided for English teachers who want to further his/her education

e) More infrastructural facilities like English laboratories should be provided for the secondary school to aid the teaching and learning of English language program

f) Teachers of English language should be motivated by increasing their welfares packages and provide more allowances for them.

\section{Acknowledgement}

I appreciate all the respondents, my family and my colleagues that supported me in the course of carrying out this project. I want to appreciate the editor team of REiLA journal for their kindness and support to publish this paper.

\section{References}

Adelabu. (2005). Teacher motivation and incentives in nigeria. Nigeria. Abasyn Journal of Social Sciences. 5(2) 78-87

Akujobi O. S. and Chukwu E. (2012). Challenges of effective English language learning in Nigerian secondary schools. International Journal of Arts and Humanities, 1 (4): 57-68.

Aremu M. A. (2014). Impacts of the use of ICT in English language pedagogy on Nigeria's National Development. International Journal of English language and linguistics research, 2 (1): 56-67.

Association for Teacher Education in Europe (2006). "The quality of teachers. Recommendations on the development of indicators to identify teacher quality.". Retrieved from: http://www. Teacher quality toolbox.eu/ uploads/quality_of_teachers_atee_def.pdf

Banjo, A. (2002). Don blames West examination of Education. Journal of the Nigerian English African Nigeria Association JNSEA Vol. 6 No 1.

Derin, T., Susilo Putri, N., Nursafira, M. S., \& Hamuddin, B. (2020). Discourse Analysis (DA) in the Context of English as a Foreign Language (EFL): A Chronological Review . ELSYA : Journal of English Language Studies, 2(1), 1-8. https://doi.org/10.31849/elsya.v2i1.3611

Evue, A. (2013). Challenges facing the teaching of English language in secondary schools in Aniocha south local government area of Delta state Nigeria."African Education Indices" 5(1), $1-11$.
Fatiloro, O. F. (2015). Tackling the challenges of teaching English language as second language (ESL) in Nigeria. IOSR journal of research \& method in education, 5(2), 26-30.

Femi, G. (2016) Educational System in Nigeria and the teacher Challenge. Bex Publisher. Abuja.

Usman, J. (2014). Challenges of teaching oral English in Nigerian high schools. Issues in Language Studies, 3(1), 15-19

Juliana C,. N. (2017). English Language, the Nigerian Education System and Human Development. UJAH Special Edition. 3(5),74-82

Junaidi, J., Hamuddin, B., Simangunsong, W., Rahman, F., \& Derin, T. (2020). ICT Usage in Teaching English in Pekanbaru: Exploring Junior High School Teachers' Problems. International Journal of Advanced Science and Technology, 29(3), 5052 - 5063. Retrieved from http://sersc.org/journals/index.php/IJAST/article/ view/5725

Kannan, R. (2009). Difficulties in learning English as a second language. ESP world, 5(26), 1-4.

Khajloo A. I. (2013). Problems in Teaching and Learning English for Students. International Journal of engineering, research and development, 7 (3): 56-58.

Khan I. A. (2011). Challenges of teaching/learning and management. Global Journal of Human Social Science, 11 (8): 68-80.

Nursafira, M. S. (2020). TED Talks in EFL Context: An Alternative Way for Teaching and Improving Student's Speaking Skills. ELSYA : Journal of English Language Studies, 2(2), 7-11. https://doi.org/10.31849/elsya.v2i2.3968

Nwiyi, G. U. (2018). Administration of Private Secondary Education in a Dwindling Economy in Nigeria. Journal of Resourcefulness and Distinction, 16(1). 215-225

Obanya, P. (2004). The dilemma of education in Africa. Ibadan: Heinemann Educational Books.

Okoroma, N. S. (2016). Oil Pipeline Vandalization in the Niger Delta: Implications for Funding Education in Nigeria. Nigerian Journal of Oil And Gas Technology, 1(1), 8-18.

Fatiloro, O. F. (2015). Tackling the challenges of teaching English language as second language (ESL) in Nigeria. IOSR journal of research \& method in education, 5(2), 26-30.

Oribabor, O. A. (2009). A Critical Review of the Involvement of Teachers and Students' Interest in Current English Language Curriculum in 
Nigerian Secondary. African Research Review, 3(1). 414-424

Osai, O. J., \& Kalagbor, S. B. (2017). The Address on Umueri Airport City Project: A Template for Leadership in Nigeria. African Research Review, 11(3), 1-12.

Sujatha, P., Salaam, M., \& Opoku, A. (2017). The effects of lack of qualified english language teachers on the performance of senior high school students. a case study of selected schools in tamale metropolis. Research Journal of English Language and Literature (RJELAL). 2 (4), 56-67

Teevno R. A. (2011). Challenges in teaching and learning of English at secondary level class X. International Journal of Human Resource Studies, 1 (2): 27-35.

Tetteh, U. S., \& Nuobeikaa, D. (2015). Factors Affecting The Teaching Of English Course In Deprived Communities, Ghana. African Journal of Applied Research (AJAR), 2(2). 115-116

The Economist Site. (2020, March, 26). Africa's population will double by 2050 . Retrieved May, 2020, from https://www.economist.com/special

Unoh, S. (1986). The study of reading. Ibadan: University Press.

Usman I,. G. (2015) English as a second language teachers' perception of new English language curriculum in Niger state, Nigeria. European Journal of Language Studies Vol. 2 (1), 2057-4797.

Yuzar, E. (2020). Incorporating Communicative Competence in Assessment and English Language Teaching in Multilingual Settings. REiLA: Journal of Research and Innovation in Language, 2(1), 8-13. https://doi.org/10.31849/reila.v2i1.3864 